\title{
STUDENTS' EXPECTATIONS ABOUT PROFESSIONAL HIGHER TECHNICAL COURSES: THE CASE OF THE BRAGANÇA'S HIGHER AGRICULTURE SCHOOL
}

\author{
M.I.B. Ribeiro"1, A.J.G. Fernandes ${ }^{1}$, A.P.R. Fernandes ${ }^{2}$ \\ ${ }^{1}$ Escola Superior Agrária, Instituto Politécnico de Bragança; Centro de Investigação de \\ Montanha, Campus de Santa Apolónia (PORTUGAL) \\ ${ }^{2}$ Faculdade de Ciências da Universidade do Porto (PORTUGAL)
}

\begin{abstract}
Forms of education for adults have two characteristics in common, namely, voluntary participation and the frequency of a course serving a specific purpose. Although some may make the choice and choose to attend a course for social reasons and others may not know clearly what they want, they all have a purpose in mind and, if they cannot reach it, sooner or later they will leave the course.

This research had as objectives to know the student's expectations about the Professional Higher Technical Course they attend; to perceive which attributes they consider to be most important for their choice; and, to identify the factors that contributed the most to the level of satisfaction with the course. A quantitative and cross-sectional study was developed based on a 62 students sample out a 298 students' universe. To collect the data, a questionnaire was developed according to the literature. The questionnaire was administered by e-mail and in the classroom, during January to July 2017, after obtaining the authorization from the head of the agriculture school. The data were analyzed using SPSS 23.0 software. The Spearman and Mann-Whitney tests were used at a significance level of $5 \%$.
\end{abstract}

The students had a mean age of 21 years old $(S D=4.25)$, were equally distributed by gender $(50 \%)$, lived in households composed with 3 people (44.3\%), with a monthly income of up to $1000 €(67.3 \%)$. Most students were displaced (54.1\%), at a distance equal or greater than $50 \mathrm{~km}$ from their residence.

The distribution of students, by course, was as follows: Veterinary Care (38.7\%); Agricultural Production (24.2\%); Food Technology (25.8\%); Environmental Management (4.8\%); Biotechnology and Innovation (3.2\%); Viticulture and Enology (3.2\%). About $53.2 \%$ of the students attended the first year and $41.7 \%$ considered that the course has a reasonable degree of difficulty, requiring a lot of effort and work. Regarding the factors that motivated the choice of the course, the most valued were, in descending order of importance, the love for the area (77.0\%), the possibility to continue the studies (36.1\%), and the career opportunities (37.1\%).

Most participants were satisfied $(36.1 \%)$ or very satisfied $(26.2 \%)$ with the course. Taking into account the location where the course took place, the results show that, in non-displaced courses, the level of satisfaction was higher than that of displaced courses. On the other hand, in non-displaced courses, the factors that are positively and moderately correlated with the level of satisfaction are: the students' opportunities to acquire theoretical knowledge and practical experience in the field, as well as the availability, support and incentive of teachers. For the rest, the level of satisfaction was positively and strongly correlated with factors as the knowledge and competences of the teachers and the methodologies used in the teaching.

So, to improve the working conditions of the displaced courses and to intensify the student/school relationship can contribute to improve students' loyalty toward the institution and to increase their satisfaction level.

Keywords: Training, Students, Satisfaction, Professional Higher Technical Course.

\section{INTRODUCTION}

The environment in which higher education institutions operate seems to be unstable and turbulent. Polytechnic higher education in Portugal is going through a period of great changes. The creation of the Professional Higher Technical Courses (PHTC) is an example of this. Officially created in 2014 by the Decree-Law no. 43/2014 of March 18, these courses, with a duration of 2 years, are a new typology of Higher Education formation. PHTC have been created with the objective of better matching the educational offer both to the diversity of demand and to the needs of the country [1]. According to 
this law, polytechnic higher education system is the responsible by the PHTC. These courses have in its structure, a component of general and scientific training, a component of technical training and a component of training in the context of work (internship).

In a challenging and highly competitive labor market with an increasingly diverse population and workforce, integration into the labor market deserves special attention as students invest much of their time, energy and resources in their education and, as such, they create high expectations regarding the future career $[2,3]$.

Academic satisfaction is a current topic that has been intensively analyzed in order to try to understand what the student perceives, his notion of the surround, the importance he gives to certain factors, the expectations he creates, to intervene in the educational process, for the continuous improvement of learning conditions and for all that is directly or indirectly related to the educational process [4].

Forms of education for adults have two characteristics in common, namely voluntary participation and the frequency of a course serving a specific purpose. Although some may make the choice and choose to attend a course for social reasons and others may not know clearly what they want, they all have a purpose in mind and, if they cannot reach it, sooner or later they will leave the course [5]. There are several reasons that may lead to dropping out of school, namely the ease of finding an unskilled job, the economic difficulties and the low purchasing power of families, the lack of motivation for the school in general, the sacrifice that must be made to overcome distances, among others [6]. On the other hand, when finishing a professional course, it is necessary to decide whether to find a job in the training area or to try to continue the studies, with the course functioning as a lever for access to higher education [7].

Students are increasingly seeking institutions that provide them with unique, memorable and personal educational experiences by attending courses that prepare them for the job market and enable them to pursue a paid profession with success [8]. The student's satisfaction with the institution, course and its functioning, namely physical facilities (available resources and infrastructures); availability; courtesy; attention and empathy of teachers, employees and colleagues; faculty competencies for the performance of their duties; as well as, the possibility of acquiring skills and knowledge in an area to which they feel they are essential factors that affect the perception of quality and, as such, influence the level of satisfaction with the course and the institution that the students choose to attend. Student satisfaction helps to build self-confidence and that self-confidence helps students to develop useful skills and to acquire knowledge [9]. In this perspective, knowledge about satisfaction factors is particularly important since several researches account for about $20-30 \%$ of students dropping out the course and the institution if they are not satisfied [10]. On the other hand, satisfaction affects students' performance [11], being a predictor of their continuity in the course and in the institution [9]. Parental support and encouragement also play an important role in the choice of the course and of the institution, as well as in the expectations created around these choices [12].

The objective of this research was to know the expectations of the students who attended Bragança's Higher Agriculture School (BHAS); to perceive which attributes were considered the most important for the course choice; and, to identify the factors that contributed the most to the level of satisfaction with the course. To this purpose, this work was developed and structured in four sections, namely, the introduction, methodology, results and discussion, and finally the conclusion. In this section, the objectives are presented, the study is justified, the work is structured and the literature is reviewed in order to theoretically frame the study. The second section describes the materials and methods used to conduct this research, i.e. participants, materials and procedures. In the third section, the results of the statistical analysis are presented and discussed. Finally, in the fourth and last section, the final considerations, limitations of the research and future research are presented.

\section{METHODOLOGY}

A cross-sectional, quantitative and analytical study was carried out to achieve the objectives. This study assumes a cross-sectional nature, because the information was collected only once, providing a "snapshot" of the relevant variables for the study at a given moment [13]. On the other hand, the study can be classified as quantitative because it allows the representation of acquired knowledge in the form of graphs, diagrams and calculations [13]. Finally, this study is analytical because, besides involving the calculation of descriptive statistics, it allows to study the association between variables [13]. 
To collect the data, a questionnaire based on the literature was administered, directly by e-mail or in the classroom, to 62 students of BHAS out of 298. Prior to the administration of the questionnaire, an authorization was requested to the head of the school. The questionnaire took no more than ten minutes to complete. Furthermore, it did not require the student's personal identification in order to guarantee their anonymity. Data collection took place during January to June 2017.

Subsequently, the collected data were analyzed using the IBM SPSS Statistics version 23.0 software. Initially, a descriptive study was carried out, which involved the calculation of descriptive statistics, namely, the calculation of absolute and relative frequencies for qualitative variables and measures of central tendency and dispersion for variables of a quantitative nature $[14,15]$. Subsequently, an analytical study was carried out to study the correlation between the factors presented on Table 1 (scale of 1 to 5 , where 1 - Very bad, 2 - bad, 3 - reasonable, 4 - good and 5 - excellent) and the degree of satisfaction with the course (scale of 1 to 5 , where 1 - very unsatisfied, 2 - unsatisfied, 3 not unsatisfied nor satisfied, 4 - satisfied and 5 - very satisfied). Therefore, the Spearman's ordinal correlation test was used $[14,15]$. The correlation coefficient or Spearman's Rho can vary between -1 (perfect inverse correlation) and 1 (perfect direct correlation) [16]. Spearman's ordinal correlation test allows to test the hypotheses $\left(H_{0}\right.$ : There is no correlation between the factor and the degree of satisfaction with the course versus $H_{1}$ : There is correlation between the factor and the degree of satisfaction with the course).

In order to compare the degree of satisfaction with the course according to the location (Bragança versus other), the Mann-Whitney's test was used [14,15]. This test enables to test the null hypothesis of the equality of medians $\left(H_{0}: \eta_{1}=\eta_{2}\right)$ against the alternative hypothesis of not all medians being equal $\left(H_{0}: \eta_{1} \neq \eta_{2}\right)$, where $\eta$ is the median.

Table 1. Factors used to evaluate students' expectations

\begin{tabular}{c|l}
\hline \hline$\#$ & \multicolumn{1}{|c}{ Factor } \\
\hline 1 & The Bragança's Higher Agriculture School (responsible for the teaching of the course) \\
\hline 2 & The resources available (classrooms, laboratories, air conditioning, ...) \\
\hline 3 & The theoretical knowledge acquired during the course \\
\hline 4 & The practical knowledge acquired during the course \\
\hline 5 & The functioning of the course you attend \\
\hline 6 & The pedagogical resources (computers, projector, didactic material, ...) \\
\hline 8 & The performance of teachers \\
\hline 9 & The enthusiasm in the teaching of classes by teachers \\
\hline 10 & The methodology used in teaching \\
\hline 11 & The availability and support of teachers \\
\hline 12 & The availability and support of the heath of the course \\
\hline 13 & The knower's communication \\
\hline 14 & The relationship with teachers \\
\hline 15 & The clarity and logical sequence in the presentation of the subjects taught \\
\hline 16 & The phase of student's life \\
\hline 17 & The relationship with other colleagues \\
\hline 18 & The reinforcement on students' confidence in their learning skills \\
\hline 19 & The progression of students' knowledge in the area of the course \\
\hline 20 & The student's school performance \\
\hline 21 & The opportunities to learn from other colleagues from the course \\
\hline 22 & The development of skills and knowledge that prepare the student for the labor market \\
\hline 23 & The development of skills for conflict resolution \\
\hline 24 & The development of communication skills \\
\hline 25 & The development of a critical spirit \\
\hline 26 & The opportunity to have practical experience in the field \\
\hline \hline
\end{tabular}


For the execution of the analytical study, the degrees of confidence $(1-\alpha)$ of $99 \%$ and $95 \%$ were used, corresponding to a level of significance $(\alpha)$ of $1 \%$ and $5 \%$, respectively. The statistical decision rule is to reject the null hypothesis $\left(H_{0}\right)$ when $p$-value is less or equal to the level of significance, that is, when $p$-value $\leq \alpha$ [14]. The probability of significance or $p$-value is the lowest level of $\alpha$ for which it is possible to reject $\mathrm{H}_{0}[14]$.

\section{RESULTS}

The average age of the students was 21 years old $(S D=4.25)$. The sample was equitably distributed by gender $(50 \%)$. They lived in households with 3 people $(44.3 \%)$, with a monthly income of up to $1000 €(67.3 \%)$, and they were displaced $(54.1 \%)$ at a distance equal or greater to $50 \mathrm{~km}$ from their residence (Table 2). The proximity of the parents' residence is considered by the student as a factor that determines the choice of the institution and the course [17].

Table 2. Sample's characterization

\begin{tabular}{|c|c|c|c|}
\hline Variable & Categories & $n$ & $\%$ \\
\hline \multirow{2}{*}{$\begin{array}{l}\text { Sex } \\
(N=62)\end{array}$} & Male & 31 & 50.0 \\
\hline & Female & 31 & 50.0 \\
\hline \multirow{6}{*}{$\begin{array}{l}\text { Course } \\
(\mathrm{N}=62)\end{array}$} & Veterinary Care & 24 & 38.7 \\
\hline & Agricultural Production & 15 & 24.2 \\
\hline & Environmental Management & 3 & 4.8 \\
\hline & Biotechnology and Innovation & 2 & 3.2 \\
\hline & Viticulture and Enology & 2 & 3.2 \\
\hline & Food Technology & 16 & 25.8 \\
\hline \multirow{2}{*}{$\begin{array}{l}\text { Year attended } \\
(\mathrm{N}=62)\end{array}$} & First & 33 & 53.2 \\
\hline & Second & 29 & 46.8 \\
\hline \multirow{3}{*}{$\begin{array}{l}\text { Distance } \\
(\mathrm{N}=61)\end{array}$} & $<50 \mathrm{Km}$ & 29 & 45.9 \\
\hline & 50 to $100 \mathrm{Km}$ & 21 & 34.4 \\
\hline & $>100 \mathrm{Km}$ & 12 & 19.7 \\
\hline \multirow{4}{*}{$\begin{array}{l}\text { Location where the PHTC was functioning } \\
(N=61)\end{array}$} & Bragança & 26 & 42.6 \\
\hline & Amarante & 2 & 3.3 \\
\hline & Marco de Canaveses & 15 & 24.6 \\
\hline & Santo Tirso & 18 & 29.5 \\
\hline \multirow{5}{*}{$\begin{array}{l}\text { Household } \\
(\mathrm{N}=61)\end{array}$} & 1 person & 5 & 8.2 \\
\hline & 2 people & 8 & 13.1 \\
\hline & 3 people & 27 & 44.3 \\
\hline & 4 people & 15 & 24.6 \\
\hline & 5 or more people & 6 & 9.8 \\
\hline \multirow{6}{*}{$\begin{array}{l}\text { Monthly income level } \\
(\mathrm{N}=55)\end{array}$} & Less than 450 Euros & 6 & 10.9 \\
\hline & 451 to 600 euros & 14 & 25.5 \\
\hline & 601 to 800 Euros & 7 & 12.7 \\
\hline & 801 to 1000 Euros & 10 & 18.2 \\
\hline & \begin{tabular}{|l|}
1001 to 1400 Euros \\
\end{tabular} & 13 & 29.6 \\
\hline & More than 1400 Euros & 5 & 9.1 \\
\hline \multirow{6}{*}{$\begin{array}{l}\text { Father's educational level } \\
(\mathrm{N}=59)\end{array}$} & Less than $1^{\text {st }}$ cycle & 3 & 5.1 \\
\hline & $1^{\text {st }}$ cycle & 11 & 18.6 \\
\hline & $2^{\text {nd }}$ cycle & 17 & 28.8 \\
\hline & 3th cycle & 15 & 25.4 \\
\hline & Secondary education & 11 & 18.6 \\
\hline & Higher education & 2 & 3.4 \\
\hline \multirow{6}{*}{$\begin{array}{l}\text { Mother's educational level } \\
(\mathrm{N}=62)\end{array}$} & Less than $1^{\text {st }}$ cycle & 1 & 1.6 \\
\hline & $1^{\text {st }}$ cycle & 10 & 16.1 \\
\hline & $2^{\text {nd }}$ cycle & 13 & 21.0 \\
\hline & 3th cycle & 18 & 29.0 \\
\hline & Secondary education & 9 & 14.5 \\
\hline & Higher education & 11 & 17.7 \\
\hline
\end{tabular}


About $53.2 \%$ of students attended the first year of a PHTC. The distribution of students by course, was as follows: Veterinary Care (38.7\%); Agricultural Production (24.2\%); Food Technology (25.8\%); Environmental Management (4.8\%); Biotechnology and Innovation (3.2\%); Viticulture and Enology (3.2) (Table 2).

About $41,7 \%$ considered that the course has a reasonable degree of difficulty, requiring a lot of effort and work (Figure 1). Most students were satisfied (36.1\%) or very satisfied (26.2\%) (Figure 2). Several surveys show that, in general, students confirm that they were quite satisfied with their experience in higher education. A well organized and trouble-free course is the main motive for the institution to meet the students' expectations [18].

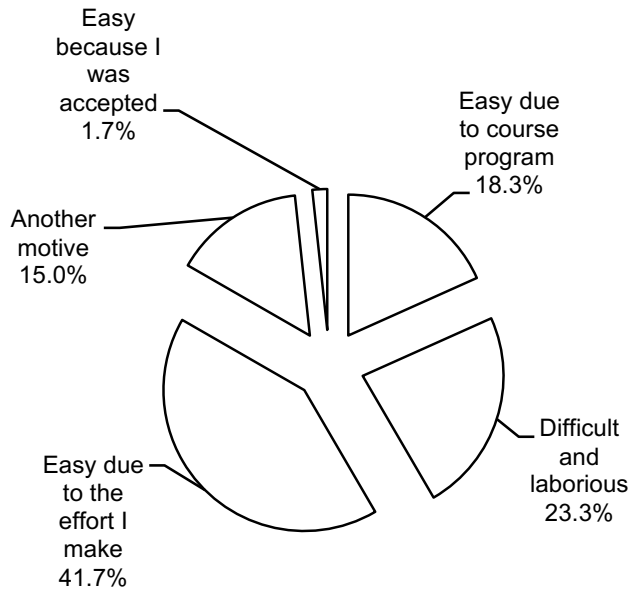

Figure 1. Degree of difficulty of the course.

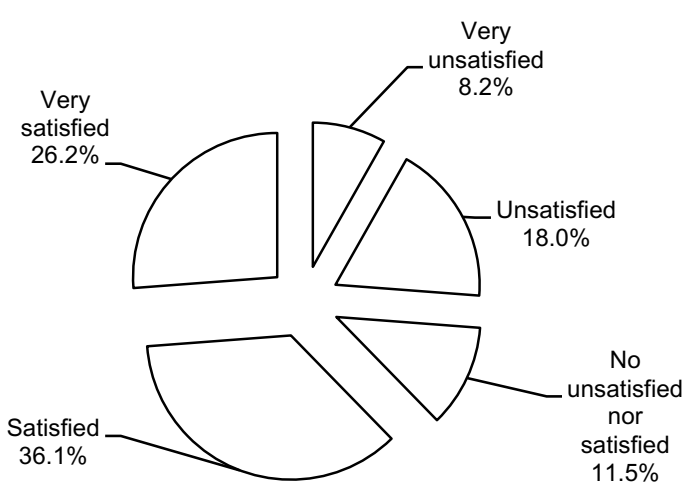

Figure 2. Satisfaction with the course.

The factors that most contributed to the choice of the course were the love for the area $(77.0 \%)$; their potential in terms of career opportunities (37.7\%); and the fact that the course allows the progression of studies since $36.1 \%$ intend to obtain a degree in the same institution (Figure 3 ). Of the $11.5 \%$ who mentioned other reasons to choose the course, they referred to the acquisition of new skills, the fact that the course they applied for did not open and, finally, because they work in the area. Students hope to receive counseling and guidance from the institutions to assist them in their future professional life in and beyond the course [19]. Hence, it is necessary to go far beyond the skills and experience for a good integration in the labor market, being extracurricular activities and internships fundamental.

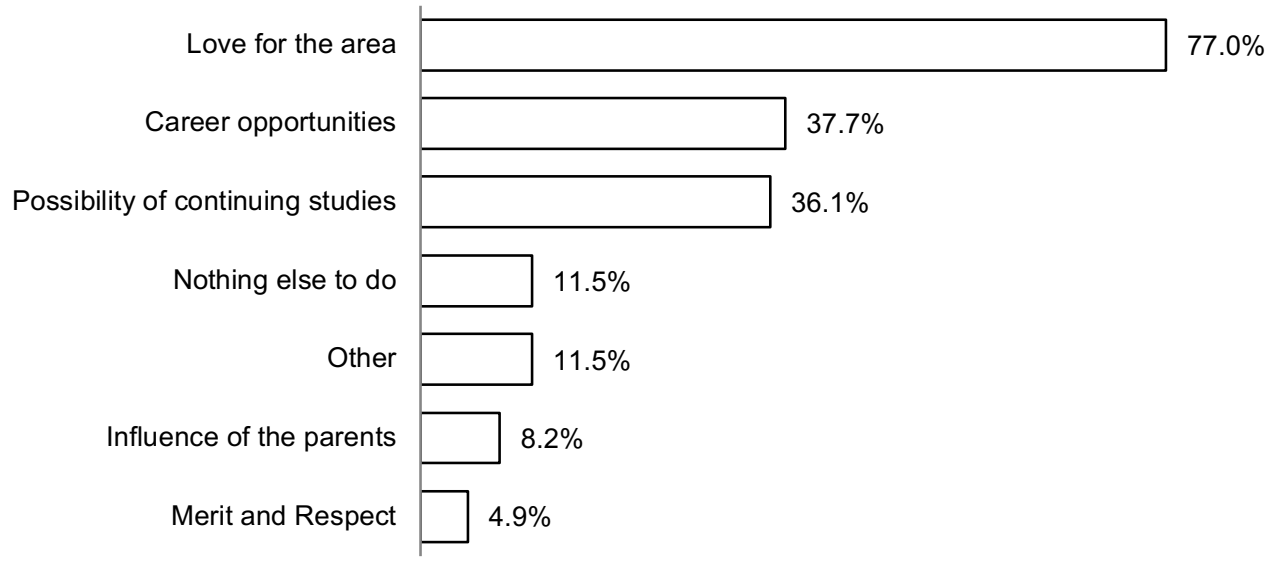

Figure 3. Reasons to choose the course

Considering whether the course was displaced or not, the results of the Mann-Whitney test revealed significant differences in the level of satisfaction ( $p$-value $=0.000$ ), being higher in Bragança (Mean rank $=42.2$ ) than in courses that were functioning in other locations (Mean rank $=22.2$ ). However, being part of a community and developing a sense of belonging are the most important environmental aspects to increase the level of satisfaction [19]. 
Overall, with the exception of school performance, learning opportunities with colleagues, the clarity and logical sequence of the presentation of the subjects, the student's life stage and the peer's relationship ( $p$-value $>0.05$ ), the factors were directly correlated with the level of satisfaction with the course (Table 3).

Taking into account the location where the PHTC was functioning, the results presented in Table 3 show that, in Bragança, the level of satisfaction with the course was positively and strongly correlated with factors that focus on the acquisition of theoretical knowledge ( $p$-value $=0.000$ : Rho $=0.537)$, the availability and support of the teachers ( $p$-value $=0.008$ : Rho $=0.515)$, the reinforcement of confidence in the student's learning abilities ( $p$-value $=0.000$; Rho $=0.547$ ), the development of competencies that prepare the students for the labor market ( $p$-value $=0.018$ : Rho $=0.470$ ), the development of communication skills ( $p$-value $=0.050$ : Rho $=0.395)$ and, finally, the opportunity to gain experience in a given area $(p$-value $=0.034 ;$ Rho $=0.426)$.

Table 3. Correlation between factors used to evaluate students' expectations and the level of satisfaction with the course

\begin{tabular}{|c|c|c|c|c|c|c|c|c|c|}
\hline \multirow{2}{*}{ Factor } & \multicolumn{3}{|c|}{ Overall } & \multicolumn{3}{|c|}{ Other location } & \multicolumn{3}{|c|}{ Bragança } \\
\hline & $N$ & $p$-value & Rho & $N$ & $p$-value & Rho & $N$ & $p$-value & Rho \\
\hline 1 & 61 & $0,000^{* *}$ & 0,511 & 35 & $0,050^{*}$ & 0,334 & 25 & 0,013 & 0,489 \\
\hline 2 & 61 & $0,000^{* *}$ & 0,693 & 35 & $0,000^{* *}$ & 0,662 & 25 & 0,224 & 0,252 \\
\hline 3 & 61 & $0,000^{*}$ & 0,742 & 35 & $0,000^{* *}$ & 0,718 & 25 & $0,000^{* *}$ & 0,537 \\
\hline 4 & 61 & $0,000^{*}$ & 0,684 & 35 & $0,000^{* *}$ & 0,715 & 25 & $0,041^{*}$ & 0,412 \\
\hline 5 & 61 & $0,000^{*}$ & 0,725 & 35 & $0,000^{* *}$ & 0,738 & 25 & $0,037^{*}$ & 0,419 \\
\hline 6 & 61 & $0,000^{*}$ & 0,683 & 34 & $0,000^{* *}$ & 0,565 & 25 & 0,207 & 0,261 \\
\hline 7 & 61 & $0,000^{*}$ & 0,643 & 35 & $0,000^{\star *}$ & 0,682 & 25 & 0,520 & 0,135 \\
\hline 8 & 61 & $0,000^{* *}$ & 0,673 & 35 & $0,000^{\star *}$ & 0,756 & 25 & 0,750 & 0,067 \\
\hline 9 & 61 & $0,000^{*}$ & 0,716 & 35 & $0,000^{*}$ & 0,771 & 25 & 0,317 & 0,209 \\
\hline 10 & 61 & $0,000^{\star *}$ & 0,643 & 35 & 0,001 & 0,556 & 25 & $0,008^{* *}$ & 0,515 \\
\hline 11 & 61 & $0,000^{*}$ & 0,633 & 35 & $0,000^{* *}$ & 0,558 & 25 & 0,091 & 0,345 \\
\hline 12 & 61 & $0,000^{\star *}$ & 0,576 & 35 & $0,000^{* *}$ & 0,642 & 25 & 0,220 & 0,254 \\
\hline 13 & 61 & $0,000^{* *}$ & 0,688 & 35 & $0,000^{\star *}$ & 0,756 & 25 & 0,090 & 0,346 \\
\hline 14 & 61 & $0,000 * 0$ & 0,612 & 35 & $0,000^{* *}$ & 0,636 & 25 & 0,240 & 0,244 \\
\hline 15 & 61 & $0,000^{* *}$ & 0,507 & 35 & $0,001^{\text {** }}$ & 0,552 & 25 & 0,898 & $-0,27$ \\
\hline 16 & 61 & 0,100 & 0,218 & 32 & 0,885 & 0,027 & 25 & 0,495 & 0,143 \\
\hline 17 & 61 & $0,003^{* *}$ & 0,373 & 35 & $0,030^{*}$ & 0,368 & 25 & 0,165 & 0,287 \\
\hline 18 & 61 & $0,000^{*}$ & 0,685 & 35 & $0,000^{* *}$ & 0,707 & 25 & $0,008^{* *}$ & 0,547 \\
\hline 19 & 61 & $0,000^{* *}$ & 0,535 & 35 & $0,001^{* *}$ & 0,543 & 25 & 0,070 & 0,368 \\
\hline 20 & 61 & $0,043^{*}$ & 0,535 & 35 & 0,082 & 0,298 & 25 & 0,191 & 0,270 \\
\hline 21 & 61 & $0,004^{* *}$ & 0,368 & 35 & $0,011^{*}$ & 0,424 & 25 & 0,383 & 0,183 \\
\hline 22 & 61 & $0,000^{*}$ & 0,630 & 34 & $0,000^{\star *}$ & 0,631 & 25 & $0,018^{*}$ & 0,470 \\
\hline 23 & 61 & $0,000^{* *}$ & 0,569 & 35 & $0,000^{\star *}$ & 0,585 & 25 & 0,129 & 0,312 \\
\hline 24 & 61 & $0,000^{*}$ & 0,649 & 35 & $0,000^{\star *}$ & 0,699 & 25 & $0,050^{*}$ & 0,395 \\
\hline 25 & 61 & $0,000^{* \star}$ & 0,580 & 35 & $0,000^{\star \star}$ & 0,625 & 25 & 0,265 & 0,232 \\
\hline 26 & 61 & $0,000^{*}$ & 0,716 & 35 & $0,000^{\star *}$ & 0,710 & 25 & $0,034^{*}$ & 0,426 \\
\hline
\end{tabular}

* There is a significant correlation at the level of significance of $1 \%$

** There is a significant correlation at the level of significance of $5 \%$

For the PHTC operating in other locations (Amarante and Marco de Canaveses), the level of satisfaction was correlated with the BHAS ( $p$-value $=0.050$ : Rho $=0.334)$, the practical knowledge acquired in the course ( $p$-value $=0.000$ : Rho $=0.718$, the teacher performance ( $p$-value $=0.000$; Rho $=0.682)$ and enthusiasm ( $p$-value $=0.000$; Rho $=0.756)$, the relationship with teachers $(p$-value $=$ 0.000 ; Rho $=636$ ), the methodology used in teaching ( $p$-value $=0.000 ;$ Rho $=0.771)$ and, finally, the development of competences for conflict resolution ( $p$-value $=0.000$; Rho $=0.585$ ), as can be seen in Table 3. These are factors that focus on the student-teacher relationship and the pedagogical conditions, infrastructures and materials available to a good functioning of the course. The students hoped to have a learning environment with certain standards, namely at the instrumental level (computers and facilities); organizational (schedule and structure of the course); interpersonal (support 
and commitment of staff) and academic (knowledge and attitude of teachers towards students). Facilities and resources are critical to ensuring an active and collaborative environment that enables the student to learn and succeed. On the other hand, students consider that, to be motivated, it is fundamental to have teachers who are "passionate" and knowledgeable about the subjects they teach [19]. Teachers' competences as well as the interaction of the student group with the teachers are important factors in the expectations created by the students [18].

\section{CONCLUSIONS}

This research had as objectives to know the expectations of the students of the PHTC that they attended; to identify the attributes they considered to be most important for their choice; and, to identify the factors that contributed the most to the level of satisfaction with the course.

The students, aged between 18 and 39, were equally distributed by gender. They lived in households with 3 people with a monthly income of up to 1000 euros. Most students were displaced within $50 \mathrm{~km}$ of their home.

Regarding the factors that motivated the choice of the course, the most valued were, in descending order of importance, the love for the area, the possibility of continuing the studies, the influence of the parents and the potential of the course in terms of career opportunities.

Taking into account the location where the course was functioning, the results show that, in Bragança, the level of satisfaction with the course was positively and strongly correlated with factors that focus on the theoretical and practical knowledge acquired, as well as the opportunity to gain experience in a given area and the development of skills that prepare the students for the labor market. For the rest, the level of satisfaction was correlated with factors that focus on the student-teacher relationship; and, the conditions, infrastructures and pedagogical materials available for the operation of the course.

To improve the operating conditions of displaced courses, namely resources and infrastructures (classrooms and laboratories); to provide more pedagogical equipment to support classes (computers, projectors and microscopes); to intensify and to improve the student-BHAS relationship; to implement practical classes, especially at the clinical practice level in the case of the Veterinary Care course; and, to increase the number of field trips can contribute to the increase the loyalty and the level of satisfaction.

\section{ACKNOWLEDGEMENTS}

The authors are grateful to the Foundation for Science and Technology (FCT, Portugal) and the ERDF under the PT2020 program for the financial support to CIMO (UID/AGR/00690/2019).

\section{REFERENCES}

[1] Decreto-Lei no 43/2014 de 18 de março. "Criação dos cursos Técnicos Superiores Profissionais", Diário da República, 1. ${ }^{a}$ série - N. ${ }^{\circ} 54$ - 18 de março de 2014. Ministério da Educação, 2014.

[2] F. Wood, "Preventing postparchment depression: a model of career counseling for college seniors", Journal of Employment Counseling, vol. 41, n² 2, pp. 71-79, 2004.

[3] J. Hurst \& L. Good, "Generation $Y$ and career choice: The impact of retail career perceptions, expectations and entitlement perceptions", Career Development International, vol. 14, $\mathrm{n}^{\circ}$ 6, pp. 570-593, 2009.

[4] N. Adubeiro, "Avaliação da Satisfação dos Estudantes do Curso de Radiologia da Escola Superior de Tecnologia da Saúde do Porto", Tese de mestrado em Gestão e Economia da Saúde, Faculdade de Economia da Universidade de Coimbra, 2010.

[5] F. Bacellar \& A. Ikeda, "Objetivos e Expectativas de Alunos de MBA Executivos", Revista de Administração da UNIMEP, vol. 3, n 3, pp. 70-90, 2005.

[6] L. Caetano, "Abandono escolar: repercussões sócio-económicas na região Centro. Algumas reflexões”, Finisterra, vol. 79, pp. 163-176, 2005.

[7] N. Schwab \& M. Lazarotto, "Percepções e expectativas dos alunos do curso técnico em paisagismo", Regae: Rev. Gest. Aval. Educ., vol. 2, nº 4, pp. 23-32, 2013. 
[8] D. Sudharani \& M. Kalpana, "Students' Expectation, Perception and Satisfaction towards the Management Educational Institutions". Procedia Economics and Finance, vol. 2, pp. 401-410, 2012.

[9] D. Letcher \& J. Neves Determinant of undergraduate business student satisfaction. Research in Higher Education Journal, pp. 1-26, 2010.

[10] B. Bogdan Sojkin, P. Bartkowiak \& A. Skuza, A. Determinants of higher education choices and student satisfaction: the case of Poland. High Educ, vol. 63, pp. 565-581, 2012.

[11] G. Pike, "The effects of background, coursework, and involvement on students' grades and satisfaction”, Research in Higher Education, vol. 32, n 1, pp. 15, 1991.

[12] J. Sia \& Ismail, "Recruitment in higher education institution: the mediating role of parents' expectations and encouragement", International Journal of Management in Education, vol. $10, \mathrm{n}^{\circ}$ 2, pp. 185-203, 2016.

[13] C. Jung, "Metodologia para pesquisa e desenvolvimento", Rio de Janeiro: Editora Axcel Books do Brasil, 2004.

[14] J. Maroco, "Análise Estatística com o SPSS statistics", Pero Pinheiro: ReportNumber, 2018.

[15] M. Pestana \& J. Gageiro, "Análise de Dados para Ciências Sociais: A complementaridade do SPSS”, Lisboa: Edições Sílabo, 2014.

[16] R. Guimarães \& J. Cabral, "Estatística”, Lisboa: McGraw-Hill, 2007.

[17] S. Temple, "Factors that Influence Students' Desires to Attend Higher Education", Seton Hall University Dissertations and Theses (ETDs). Paper 420, 2009.

[18] Universities UK, "Student experience: measuring expectations and outcomes", Universities UK, 2016.

[19] C. Kandiko \& M. Mawer, "Student Expectations and Perceptions of Higher Education", London: King's Learning Institute, 2013. 